Abstracta Iranica Abstracta Iranica

Revue bibliographique pour le domaine irano-aryen

Volume 25 | 2004

Comptes rendus des publications de 2002

\title{
A la croisée des voies célestes: Faxr al-din 'Erâqi - Poésie mystique et expression poétique en Perse médiévale. Téhéran, IFRI, Bibliothèque Iranienne 56, 2002, 347 p.
}

Pierre Lory

\section{(2) OpenEdition}

\section{Journals}

Édition électronique

URL : http://journals.openedition.org/abstractairanica/4915

DOI : 10.4000/abstractairanica.4915

ISSN : 1961-960X

Éditeur :

CNRS (UMR 7528 Mondes iraniens et indiens), Éditions de l'IFRI

Édition imprimée

Date de publication : 15 mai 2004

ISSN : 0240-8910

\section{Référence électronique}

Pierre Lory, "A la croisée des voies célestes : Faxr al-din 'Erâqi - Poésie mystique et expression poétique en Perse médiévale. Téhéran, IFRI, Bibliothèque Iranienne 56, 2002, 347 p. », Abstracta Iranica [En ligne], Volume 25 | 2004, document 255, mis en ligne le 15 mars 2006, consulté le 25 septembre 2020. URL : http://journals.openedition.org/abstractairanica/4915; DOI : https://doi.org/10.4000/ abstractairanica. 4915

Ce document a été généré automatiquement le 25 septembre 2020.

Tous droits réservés 


\section{A la croisée des voies célestes : Faxr al- din 'Erâqi - Poésie mystique et expression poétique en Perse médiévale. Téhéran, IFRI, Bibliothèque Iranienne 56, 2002, 347 p.}

\section{Pierre Lory}

Ce travail, résultat d'une thèse de doctorat, est une présentation en profondeur de l'œuvre de 'Irāqī dans sa double dimension mystique et littéraire. E.F.-P. y décrit l'œuvre du grand poète, les traits fondamentaux de sa doctrine de l'amour, du cheminement vers Dieu, bref de sa 'théologie mystique'. Mais cet exposé n'est pas dissocié des formes littéraires qu'il utilise, soulignant si besoin était combien l'usage du discours humain fait partie de l'expérience de soi. C'est un ouvrage qui marque une borne dans notre connaissance de cette belle figure de l'histoire culturelle persane.

\section{INDEX}

Thèmes : 8 . Soufisme 
AUTEURS

PIERRE LORY

EPHE - Paris 